\title{
DEVELOPMENT OF MODEL OF PLANT FOR MEASURING DISPERSIVITY OF MATERIAL IN ENERGY-CARRIER FLOW BASED ON REGRESSION
}

\section{ANALYSIS}

Institute of Technical Mechanics of the National Academy of Sciences of Ukraine and the State Space Agency of Ukraine,

15, Leshko-Popel Str., Dnepr, Ukraine, 49005,e-mail: np-2006@ukr.net

Based on experimental investigations, the plant for measuring the material particle size in the flow has been created. The work objective is to develop a regression model for determining the material dispersivity in the flow to update the plant considering its geometrical parameters. The basic factors affecting the characteristics of the acoustic signals recorded during the material transportation have been found. The influence of each accepted factor and their effects on the maximum amplitude of the acoustic signals with the determination coefficient $\mathrm{R}=$ 0.9 is estimated. The constructed regression model allows improvements in the plant for determining dispersivity of the bulk material in the flow.

Keywords: granulometric composition, acoustic signals, factor, amplitude, regression model.

1.Ternovaya Ye. $V$. Estimation of modern techniques for granulometric analysis of grinding product. Zbagachennya Korysnykh Kopalyn. 2014. No 58 (99) - 59 (100). P. 71 - 78.

2. Pryadko N. S. Acoustic and emission monitoring a process of jet grinding. Tekhnicheskaya Diagnostika i Nerazrushayushchiy Kontrol. 2012. No 6. P. $46-52$.

3. Pryadko N. S. Evolution of Theory of Fine Minerals Grinding; Abstract for Doctor's (Eng.) Thesis: 05.15.08 NGU. Dniepropetrovsk, 2015. 36 p.

4. Pilov P. I., Gorobets L. Zh., Pryadko N. S. Regular variations in acoustic signals in relation to dispersivity in ore jet grinding. Zbagachennya Korysnykh Kopalyn. NGU: Dniepropetrovsk. 2013. No 54 (95). P. 52 - 61.

5. Application a2015 07099 Ukraine, Int. Cl. B 02 C 19/06. Method for Measuring Granulometric Composition of Bulk Material in Flow / Pylov P. I., Gorobets L. Zh., Praydko N. S., Ternova K. V.; applicant and patentee Institute of Technical Mechanics, NASU\&SSAU, filed 16.07.2015.

6. Pryadko N. S., Ternovaya Ye. V. Experimental investigations into characteristics of acoustic signals in conveying materials through "Granulometr" plants. Zbagachennya Korysnykh Kopalyn. 2016. No 64 (105). P. $111-118$ 